\title{
Profile of hospitalizations and prevalence of conditions sensitive to primary care in a university hospital
}

\author{
Perfil de internações e prevalência de condições sensíveis à atenção primária em hospital \\ universitário
}

Lucia Aparecida de Souza ${ }^{1}$, Ricardo de Mattos Russo Rafael ${ }^{2}$, Anna Tereza Miranda Soares de Moura ${ }^{2}$, Mercedes Neto $^{3}$

Objective: to describe the profile of hospitalizations and the prevalence of conditions sensitive to primary care in the medical clinic sector. Methods: exploratory cross-sectional study with 197 subjects hospitalized for over 24 hours. Data collected from interviews and medical records collection of hospitalized patients in the sector and analyzed through descriptive statistics. Results: adults, females, black skinned people, with 4-12 years of schooling, belonging to class $\mathrm{C}$ and residents of the urban zone predominated among the hospitalized people. The prevalence of hospitalizations due to sensitive conditions was 20.8\% (Confidence Interval 95.0\%: 15.7/27.1). Diseases of the respiratory tract, skin and subcutaneous tissue presented higher prevalence than the general estimate of hospitalizations for conditions sensitive to Primary Care. Conclusion: hospitalizations occurred predominantly in middle-class adults with up to 12 years of schooling. The frequency of hospitalizations due to sensitive conditions was high, and mainly due to circulatory, respiratory, digestive and genitourinary diseases.

Descriptors: Health Services; Hospitals, University; Comprehensive Health Care; Indicators of Health Services.

Objetivo: descrever o perfil das internações e a prevalência de condições sensíveis à atenção primária no setor de clínica médica. Métodos: estudo exploratório transversal com 197 sujeitos internados há mais de 24 horas. A coleta de dados ocorreu com entrevistas e coleta de prontuário de pacientes hospitalizados no setor. A análise foi estatística descritiva. Resultados: observou-se predomínio de internações de adultos, do sexo feminino, negros, com estudo entre quatro e 12 anos, de classe C e residentes da zona urbana. A prevalência de internações por condições sensíveis foi de 20,8\% (Intervalo de Confiança de 95,0\%:15,7/27,1). As doenças do aparelho respiratório, pele e tecido celular subcutâneo apresentaram prevalências superiores à estimativa geral de internações por condições sensíveis à Atenção Primária. Conclusão: as internações ocorreram, predominantemente, em adultos de classe média e com até 12 anos de estudo. As internações por condições sensíveis foram elevadas, sobretudo por doenças do aparelho circulatório, respiratório, digestivo e geniturinário. Descritores: Serviços de Saúde; Hospitais Universitários; Assistência Integral à Saúde; Indicadores de Serviços.

\footnotetext{
${ }^{1}$ Universidade Federal de Juiz de Fora. Juiz de Fora, MG, Brazil.

${ }^{2}$ Universidade do Estado do Rio de Janeiro, Universidade Estácio de Sá. Rio de Janeiro, RJ, Brazil.

${ }^{3}$ Universidade do Estado do Rio de Janeiro. Rio de Janeiro, RJ, Brazil. 


\section{Introduction}

Changes in lifestyle, especially in the last decades, have brought important alterations in the burden of diseases among the Brazilian population, what invariably makes us reflect on the need to build an articulated service network. The chronic nature of some health problems and the increasing dependence of users on systems require more effective and efficient public policy interventions. In this sense, Brazilian public policies have centralized the coordination of the care and organization of the Health Care Network in the Primary Health Care services ${ }^{(1)}$.

To fulfill its role in the Health Care Network, the Primary Care needs to promote integrated and quality care and services, according to the needs and socioeconomic, cultural and demographic conditions of the population. The development of actions at this level of care has been shown to be effective in reducing avoidable hospitalizations ${ }^{(2-3)}$. These hospitalizations can be monitored by means of the indicator of hospitalizations due to sensitive conditions to the Primary Care, a parameter developed by a North American researcher in the 20th century, and defined as a group of health problems whose risk of hospitalization can be controlled or reduced through the implementation of effective strategies of the first level of attention ${ }^{(3)}$.

In order to the evaluate health services, particularly the Primary Health Care, and aiming to subsidize more effective and robust public policies, the Ministry of Health adopted the List of Conditions Sensitive to Primary Care after adjusting it to the national reality ${ }^{(3)}$, becoming an important tool in the context of scientific production and management of health services in Brazil. Although research shows that the presence of primary health care contributes to reduce the risk of hospitalizations due to conditions sensitive to primary care ${ }^{(4-5)}$, it is notable that this phenomenon does not occur in a linear manner throughout the national territory ${ }^{(6-7)}$.

The indicator alone is not enough to evaluate Primary Health Care, but it gives the possibility of processing a network organization analysis, aiming at the principle of integrality ${ }^{(8)}$. Another factor that may impact the hospitalizations due to Conditions Sensitive to Primary Care is the personal choices of users, among them, the search for more complex services as a gateway to the system in response to the difficulties related to organization of the network and the stigma that specialized services have of being more resolutive $\mathrm{e}^{(9)}$.

In this context, besides providing specialized and high complexity services, university hospitals have the mission of teaching, promoting research and outreach projects. The recurrent absence of centralized practices in the continuity of care between these hospitals and primary care services may increase the desire for hospitalizations, which are many times unnecessary ${ }^{(10)}$.

Studies on these hospitalizations in the scenario of university hospitals are unprecedented, and thus it is expected that the present work subsidize the formulation and expansion of integrative strategies of these units to the Health Care Network. Considering the social commitment of Nurses with qualified care, either in primary care or the tertiary network, we believe that the knowledge produced here may become useful to the reflection-action binomial of this profession, especially with regard to the coordination of care. The present research aims to describe the profile of hospitalizations and the prevalence of conditions sensitive to primary care in the medical clinic sector.

\section{Methods}

An exploratory cross-sectional study was developed in the period from March to June 2016 at the medical clinic unit of a university hospital in the city of Juiz de Fora, MG, Brazil. The municipality is located in the forest zone of Minas Gerais and had an estimated population of 555,284 inhabitants in 2015. Primary Health Care covers $81.0 \%$ of the population and has a high suppressed demand for secondary-level services; the most deficient specialties are cardiology, endocri- 
nology, orthopedics and neurology ${ }^{(11)}$.

Juiz de Fora is the hub of the macro and micro-region of southeast Minas Gerais according to the Master Plan for Regionalization of the State, being a reference for more than 1.5 million inhabitants. The university hospital integrates the municipal network, provides assistance at the primary, medium and high complexity levels, and has no emergency service. It provides a monthly average of 7,500 consultations in specialized services and 300 hospitalizations ${ }^{(12)}$. The medical clinic unit, locus of the present research, is the sector that assists patients hospitalized for diagnoses and treatments and non-surgical procedures.

The study population consisted of patients aged 18 years and older who were hospitalized for more than 24 hours. Forty-nine patients with clinical-cognitive limitations, that is, previous diagnosis of dizziness, numbness and health problems that temporarily or permanently compromised consciousness and that were described in the medical record were excluded from the interview. Patients who were discharged prior to the interview were considered losses, totaling four persons. The sample consisted of hospitalizations that occurred during a four-month period, from March to June 2016, making up a total of 197 subjects. Thus, the sampling technique was of non-probabilistic and opportunistic type, since a time cut-off was established for data collection.

After approval by the ethics committee, a pilot study was carried out in the research scenario itself, aiming to test the instrument and the dynamics of data collection. After this phase, the interviews were carried out by the first author of this study on visits to the unit on alternate days, using an individual and direct approach at the bedside, capturing the totality of eligible subjects.

To collect the data, a multidimensional questionnaire was used, the first dimension being related to sociodemographic and economic conditions such as sex, age, skin color, schooling, place of residence and economic class. The following socioeconomic stra- ta were considered: A/B (over R\$4,852.00), C (between $\mathrm{R} \$ 1,625.00$ and 4,852.00), and D-E (up to $\mathrm{R} \$$ $1,625.00)$. The second dimension was composed of questions related to health monitoring and hospitalization of the study population, and in the latter, the Brazilian list of Sensitive Conditions to Primary Care was used. This was organized by groups of causes of hospitalizations and diagnoses, according to the Tenth Revision of the International Classification of Diseases. The diagnoses were obtained through the data available in the medical records of participants.

The construction and cleaning of the database were performed in the Microsoft Excel 2010 software. The Stata 13 software was used for statistical analysis of the data after exporting and converting the Excel files. The analysis plan consists of the use of descriptive statistics for the study variables, calculating the frequencies and the respective confidence intervals to 95.0\%.

The study complied with the formal requirements contained in the national and international regulatory standards for research involving human beings.

\section{Results}

The sociodemographic and economic characterization of patients hospitalized in the medical clinic of the studied University hospital in Juiz de Fora, MG, Brazil, showed predominance of females, in the age group of 18 to 59 years, black and brown skinned, with 4 to 12 years of schooling, belonging to the economic class $\mathrm{C}$ and residents in the urban area of Juiz de Fora.

After this characterization, the Table 1 presents the profile of utilization of health services by the sample studied. It is noteworthy that most of the interviewees reported that emergency care units or other emergency units were the first services sought before hospitalization, as it happened with the type of unit that referred the patients to the university hospital. 
Table 1 - Profile of utilization of health services by patients hospitalized in the medical clinic of a University Hospital $(n=196)$

\begin{tabular}{|c|c|c|}
\hline Variables & n (\%) & $95 \% \mathrm{CI}$ \\
\hline \multicolumn{3}{|l|}{ Service sought before hospitalization } \\
\hline Primary Health Care & $30(15.2)$ & $10.8 ; 21.0$ \\
\hline University hospital & $30(15.2)$ & $10.8 ; 21.0$ \\
\hline Emergency care unit & $64(32.5)$ & $26.2 ; 39.4$ \\
\hline Others* & $73(37.1)$ & $30.5 ; 44.1$ \\
\hline \multicolumn{3}{|l|}{ Service that forwarded the patient } \\
\hline Primary Health Care & $6(3.1)$ & $1.3 ; 6.6$ \\
\hline University hospital & $39(19.8)$ & $14.8 ; 26.0$ \\
\hline Emergency care unit & $70(35.5)$ & $29.1 ; 42.5$ \\
\hline Others* & $82(41.6)$ & $34.9 ; 48.7$ \\
\hline \multicolumn{3}{|l|}{ Reason for admission to the University Hospital } \\
\hline Regulated vacancy & $97(49.5)$ & $42.5 ; 56.5$ \\
\hline $\begin{array}{l}\text { Already performing follow-up at the } \\
\text { University Hospital }\end{array}$ & $64(32.6)$ & $26.4 ; 39.6$ \\
\hline Meet someone at the University Hospital & $35(17.9)$ & $13.1 ; 23.9$ \\
\hline
\end{tabular}

When questioned about the number of hospitalizations for the presented diagnostic, about $40.0 \%$ of the sample reported that they had already been hospi- talized one or more times, $19.8 \%$ (95.0\% CI: 14.8/26.0) in the university hospital. The main reason for hospitalization was performance/confirmation of diagnosis or treatment of a known disease (P: 69.5\%, 95.0\% CI: 62.7/75.6). Although almost the entire sample made a good evaluation of the services provided by the hospital (P: 93.9\%, 95.0\% CI: 89.5/96.5), just over half of respondents also evaluated the local health services as good (P: 54.6\%, 95.0\% CI: 46.5/60.6).

Table 2 presents the profile of diagnoses, according to the chapters of the International Statistical Classification of Diseases and health-related problems (ICD-10). The prevalence of hospitalizations for Conditions Sensitive to Primary Care was 20.8\% (95.0\% CI: $15.7 / 27.1$ ) for the period studied, with a predominance of diseases of the respiratory system, skin and subcutaneous cellular tissue, and circulatory system.

Endocrine, nutritional and metabolic diseases of the digestive and genitourinary tract also deserve attention, as they presented higher prevalences than the general estimate of hospitalizations for Conditions Sensitive to Primary Care in the sector.

Table 2 - Profile of hospitalization in the medical clinic sector of a University Hospital according to the chapters of the ICD-10 and the Conditions Sensitive to Primary Care

\begin{tabular}{|c|c|c|c|c|}
\hline \multirow[t]{2}{*}{ ICD-10 chapter } & \multicolumn{2}{|c|}{$\begin{array}{l}\text { Total hospitalizations } \\
\text { (n=197) }\end{array}$} & \multirow{2}{*}{$\begin{array}{c}\begin{array}{c}\text { Hospitalization by } \\
\text { Sensitive Conditions } \\
(\mathrm{n}=41)\end{array} \\
\mathrm{n}(\%) \\
\end{array}$} & \multirow{2}{*}{$\begin{array}{c}\begin{array}{c}\text { Hospitalization by } \\
\text { other conditions } \\
(n=156)\end{array} \\
n(\%)\end{array}$} \\
\hline & n (\%) & $95 \% \mathrm{CI}$ & & \\
\hline Some infectious and parasitic diseases & $30(15.2)$ & $10.8 ; 21.0$ & $3(10.0)$ & $27(90.0)$ \\
\hline Neoplasms [Tumors] & $2(1.0)$ & $0.2 ; 4.0$ & - & $2(100.0)$ \\
\hline Blood and hematopoietic diseases and some immune disorders & $28(14.2)$ & $10.0 ; 19.9$ & - & $28(100.0)$ \\
\hline Endocrine, nutritional and metabolic diseases & $7(3.5)$ & $1.7 ; 7.3$ & $2(28.6)$ & $5(71.4)$ \\
\hline Diseases of the nervous system & $15(7.6)$ & $4.6 ; 12.3$ & $3(20.0)$ & $12(80.0)$ \\
\hline Diseases of the ear and mastoid apophysis & $1(0.5)$ & $0.1 ; 3.6$ & - & $1(100.0)$ \\
\hline Diseases of the circulatory system & $21(10.6)$ & $7.0 ; 15.8$ & $8(38.1)$ & $13(61.9)$ \\
\hline Diseases of the respiratory system & $14(7.1)$ & $4.2 ; 11.7$ & $9(64.3)$ & $5(35.7)$ \\
\hline Diseases of the digestive system & $36(18.3)$ & $13.4 ; 24.3$ & $8(22.2)$ & $28(77.8)$ \\
\hline Skin and subcutaneous tissue disorders & $3(1.5)$ & $0.5 ; 4.6$ & $2(66.7)$ & $1(33.3)$ \\
\hline Diseases of the musculoskeletal system and connective tissue & $4(2.0)$ & $0.7 ; 5.3$ & - & $4(100.0)$ \\
\hline Diseases of the genitourinary system & $28(14.2)$ & $10.0 ; 19.9$ & $6(21.4)$ & $22(78.6)$ \\
\hline Others* & $8(4.1)$ & - & - & $8(100.0)$ \\
\hline
\end{tabular}

*Symptoms, signs, and abnormal findings from clinical and laboratory tests, not classified elsewhere; injuries, poisonings and other consequences of external causes; external causes of morbidity and mortality; factors that influence the health status and contact with health services; $\mathrm{CI}=\mathrm{Confidence} \mathrm{Interval}$ 


\section{Discussion}

For the interpretation of the results of this research, it is necessary to consider the limitations of cross-sectional studies. Although it presents feasible applications, low cost, fast and excellent results, cross-sectional studies have limitations in other instances, as they do not allow longitudinal monitoring, or causal inferences. It seems important to consider the limitation on the potential of generalization of this study, since it addressed a particular case of a medical unit in Juiz de Fora. However, despite the limitations, it is relevant to consider that the work reveals an unexplored scenario in the relations about hospitalizations due to sensitive conditions, that is, the university hospitals.

It is indisputable that university hospitals, as a facility for professional training, are responsible for research and teaching, and for providing assistance in a specialized clinics, developing strong links between services and users ${ }^{(10)}$. This practice, which is widely recommended, may make it difficult to monitor the health status of users in other system levels, such as Primary Health Care. According to ICD-10 chapters, the prevalence of hospitalizations for Conditions Sensitive to Primary Care was $20.8 \%$ for the period studied. This prevalence can be considered high, as a rate of $15.1 \%$ was found in the municipality and the target was $9.3 \%$, both observed in $2015^{(12)}$.

It is worth mentioning that the prevalence was $36.6 \%$ in another city of Minas Gerais and in Brazil, this was over $30.0 \%{ }^{(13)}$. These results may indicate a high prevalence of hospitalizations due to Conditions Sensitive to Primary Care and the disarticulation of the Health Care Network, generating the need to reflect on more effective actions to respond to the fragmentation of the system, making it possible to reduce the number of these hospitalizations. The adoption of university training strategies by university hospitals, within a set of other actions, can lead to improvements in the integration of the Network, according to international experiences ${ }^{(14)}$.

Despite the reduced sample, it was possible to identify results that are in line with other studies, especially on the profile of diagnoses. Studies point to respiratory and cardiovascular diseases as the main causes of hospitalizations for sensitive conditions, besides the association of these events with chronic conditions $^{(14-15)}$. Drawing a parallel with the changing epidemiological profile of the Brazilian population, one of the factors being the increase in the incidence of chronic diseases and the lack of integrality to respond to this new demand of the population ${ }^{(4)}$, it is possible to suggest that this may be a phenomenon that interacts with the outcomes investigated. The theme deserves better scrutiny in future studies. On the other hand, the studies point to a probable association of these hospitalizations with the form of organization of Primary Attention in the Network ${ }^{(16)}$.

A university hospital should have a differentiated profile; however, the reality shows that this type of hospital seems to follow the same course of general hospitals, with hospitalizations that could actually been previously monitored in the Primary Health Care. In order to reflect on the characteristics of patients assisted in university hospital, it is necessary to take into account that the study population was composed of patients residing in the studied region and also in neighboring municipalities. Thus, the analysis of the results does not reflect the local health services but allows a notion about its actual role in the system.

The profile of the subjects, according to the socioeconomic and demographic survey, was dominated by adults aged 18-59 years, females, black and brown skinned, with low level of education, married, with low family income, and residents in the municipality area. It is assumed that the health/disease process is linked to social determinants. Poor, under-educated, minority groups, among others, are more susceptible to illnesses and hospital admissions ${ }^{(17)}$, as well as they are the target of compensatory policies sometimes practiced by the Strategy on Family Health/Primary Health Care. Such practices may be raising a repressed demand that, in the ideal hypothesis, should be monitored by the first level of attention in an articulated 
way with the others. It is up to university hospitals to provide assistance only to demands that involve complexity, technological density and research.

Regarding the predominance of women, this finding may not be plausible, since the current administration of the University Hospital provides a number of beds differentiated by gender, with more beds for women than for men, which may have resulted in a higher occurrence of hospitalizations of this group.

The data referring to the use of health services by the sample studied indicated that the emergency / urgency care unit was the gateway in the case of most of the interviewees, and this service was the one that most referred patients to hospitalizations. In general, hospitalization was regulated by a specific central sector of the local health system, or the patient was already performing some type of follow-up in the hospital unit. It is noteworthy that part of the sample studied (P: 17.9\%) reported that the hospitalization occurred due to previous knowledge/indication of a professional in the hospital.

The provision of specialized and prompt care services has assumed the function of primary care, the gateway to the system ${ }^{(7)}$. Another justification is anchored in the identification ${ }^{(8)}$ in the users' statements that the entry door has not been preferentially the Primary Health Care, due to the difficulty of access and little resolution of the assistance provided there.

On the other hand, users use their knowledge, experiences, interests and personal relationships to enter the system ${ }^{(5)}$. The author adds that, in the view of users, the "gateway" cannot be limited to norms, but must be open at any point in the network, especially in the services that identify or welcome them in their demands for assistance, provided they reflect the organizational principles of the systems.

Regarding the profile of follow-up and hospitalizations, a large percentage $(40.0 \%)$ reported that they had already been hospitalized once or more times for the same diagnosis; $19.8 \%$ of these previous hospitalizations had occurred in the university hospital. The main reason for hospitalization was the diag- nosis/confirmation or treatment of a known disease (69.5\%). These data may be related to the follow-up of users in specialized clinics in this unit, generating a bond between the service and the patient, hindering the return of the user to the Primary Health Care. The creation of bond, reception and accessibility influence the functioning of the Health Care Network and, therefore, should be included in the service program$\operatorname{ming}^{(13)}$.

Although almost the entire sample evaluated the services provided by the hospital (93.9\%) as of good quality, just over half of respondents rated likewise the local health services (54.6\%). These findings can be explained by experiences in the previous use and evaluation of health services. Previous experiences in health services and the personal, biopsychosocial and cultural needs of patients determine expectations for subsequent services. Intensifying the follow-up of high-risk users, improving the timely location of patients and extending the hours of functioning of units to facilitate access and optimize the use of services can be strategies to modify the situation and reduce the frequency of hospitalizations due to sensitive conditions ${ }^{(18)}$.

Furthermore, the approximation of the knowledge produced here with the nursing practice is considered especially relevant, mainly because we understand that these professionals are a fundamentally important part for the construction of the health systems. In this sense, subsidizing these teams with these findings may represent one of the forms of dealing with preventable hospitalizations.

\section{Conclusion}

The hospitalizations occurred predominantly among women, in adult age, black skinned, with four to 12 years of schooling, of the middle economic class and residents in the urban area of Juiz de Fora. Most of the surveyed patients sought urgency and emergency units as the first contact with the system, and these were the services that most referred patients to the 
hospital. Admissions due to conditions sensitive to primary care proved to be high, especially for diseases of the circulatory, respiratory, digestive, dermatological and genitourinary system.

\section{Collaborations}

Souza LA and Rafael RMR contributed to the design of the project, analysis and interpretation of data, writing of the article and approval of the final version to be published. Moura ATMS and Neto M contributed to the analysis and interpretation of the results, critical revision of the intellectual content and approval of the final version to be published.

\section{References}

1. Almeida PF, Santos AM. Primary Health Care: care coordinator in regionalized networks? Rev Saúde Pública. 2016; 50(80). doi: http://dx.doi. org/10.1590/S1518-8787.2016050006602

2. Borges PKO, Shawb PM, Blanski CR, Floriano LSM, Lopes BG, Muller EV. Sensitive hospitalizations to primary care and care in the health care network. Rev Rene. 2016; 17(5):668-75. doi: http://dx.doi. org/10.15253/2175-6783.2016000500012

3. Alfradique ME, Bonolo PF, Dourado I, Lima-Costa MF, Macinko J, Mendonça CS, et al. Internações por condições sensíveis à atenção primária: a construção da lista brasileira como ferramenta para medir o desempenho do sistema de saúde (Projeto ICSAP - Brasil). Cad Saúde Pública. 2009; 25(6):1337-49. doi: http://dx.doi.org/10.1590/ S0102-311X2009000600016

4. Rodrigues LBB, Silva PCS, Peruhype RC, Palha PF, Popolin MP, Crispim JÁ, et al. A atenção primaria a saúde na coordenação das redes de atenção: uma revisão integrativa. Ciênc Saúde Coletiva. 2014; 19(2):343-52. doi: http://dx.doi. org/10.1590/1413-81232014192.18032012

5. Sousa NP, Hehem TCMSB, Santos WS, Santos CE. Hospitalizations sensitive to primary health care at a regional hospital in the Federal District. Rev Bras Enferm. 2016; 69(1):118-25. doi: http:// dx.doi.org/10.1590/0034-7167.2016690116i
6. Rodrigues-Bastos R, Campos EMS, Ribeiro LC, Firmino RUR, Bustamante-Teixeira MT. Hospitalizations for primary caresensitive conditions in a Southern Brazilian municipality. Rev Assoc Med Bras. 2013; 59(2):120-7. doi: http://dx.doi. org/10.1016/j.ramb.2012.11.001

7. Melo MD, Egry EY. Social determinants of hospitalizations for ambulatory care sensitive conditions in Guarulhos, São Paulo. Rev Esc Enferm USP. 2014; 48(esp):133-40. doi: http://dx.doi. org/10.1590/S0080-623420140000600019

8. Rehem TCMSB, Ciosak SI, EGRY, Emiko Y. Ambulatory care sensitive conditions: general hospital of micro-region of São Paulo municipality, Brazil. Texto Contexto Enferm. 2012; 21(3):53542. doi: http://dx.doi.org/10.1590/S010407072012000300007

9. Uscher-Pines L, Pines J, Kellermann A, Gillen E, Mehrotra A. Deciding to visit the emergency department for non-urgent conditions: a systematic review of the Literature. Am J Manag Care [Internet]. 2013 [cited 2017 Jun 13]; 19(1):47-59. Available from: https://www.ncbi.nlm.nih.gov/pmc/ articles/PMC4156292/

10. Flink M, Bergenbrant G, Airosa F, Ohlén G, Barach P, Hansagi H, Brommels $\mathrm{M}$ et al. Patient-centered handovers between hospital and primary health care: an assessment of medical records. Int J Med Inform. 2015; 84(5):355-62. doi: http://dx.doi. org/10.1016/j.ijmedinf.2015.01.009

11. Universidade Federal de Juiz de Fora. Carta de serviços ao cidadão. Empresa Brasileira de Serviços Hospitalares (EBSERH) [Internet]. 2015 [citado 2015 mai. 16]. Disponível em: http://www. ebserh.gov.br/documents/222346/866032/ carta-de-servicos-ao-cidadao.pdf/097902fe0233-49e0-a43f-62303f09c410

12. Prefeitura Municipal da Cidade de Juiz de Fora. Secretaria Municipal de Saúde. Plano Diretor da Atenção Primária em Saúde - Projeto de Implantação [Internet]. 2014 [citado 2017 jan. 20]. Disponível em: https://www.pjf.mg.gov. br/secretarias/saude/plano_diretor/docs/ implantacao.pdf 
13. Cardoso CS, Pádua CM, Rodrigues-Júnior AA, Guimarães DA, Carvalho SF, Valentin RF, et al. Contribuição das internações por condições sensíveis à atenção primária no perfil das admissões pelo sistema público de saúde. Rev Panam Salud Publica [Internet]. 2013 [citado 2016 ago. 13];34(4):22734. Disponível em: http://www.scielosp.org/pdf/ rpsp/v34n4/03.pdf

14. Laberge M, Wodchis WP, Barnsley J, Laporte A. Hospitalizations for ambulatory care sensitive conditions across primary care models in Ontario, Canada. Soc Sci Med. 2017; 181:24-33. doi: 10.1016/j.socscimed.2017

15. Busby J, Purdy S, Hollingworth W. A systematic review of the magnitude and cause of geographic variation in unplanned hospital admission rates and length of stay for ambulatory care sensitive conditions. BMC Health Serv Res. 2015; 15:324. https://doi.org/10.1186/s12913-015-0964-3
16. Gonçalves MR, Hauser L, Prestes IV, Schmidt MI, Bartholow B, Harzheim E. Primary health care quality and hospitalizations for ambulatory care sensitive conditions in the public health system in Porto Alegre, Brazil. Fam Pract; 2015; 33(3):23842. doi: 10.1093/fampra/cmv051

17. Oliveira MJI, Santo EE. A relação entre os determinantes sociais da saúde e a questão social. Cad Saúde Desenvolvimento [Internet]. 2013 [citado 2016 jun. 26]; 2(2):7-24. Disponível em:www.uninter.com/cadernosuninter / index.php/saude-e-desenvolvimento/article/ download/253/243

18. Freund T, Campbell SM, Geissler S, Kunz CU, Mahler C, Peters-Klimm F, et al. Strategies for reducing potentially avoidable hospitalizations for ambulatory care-sensitive conditions. Ann Fam Med. 2013; 11(4):363-70. doi: 10.1370/ afm.1498 